eye : and on being reflected backward, the light is received by the examiner's eye with sufficient intensity to create an image."

On page 38 in discussing the tortuosity of the retinal vessels he comments that "straight vessels are apt to be normal vessels." Friedenwald has shown that straightness of the retinal vessels with branches coming off at acute angles is a pathological manifestation associated with arteriosclerosis. In discussing the causes of darkness of the retinal vessels Vaquez's disease has been omitted, and in the section dealing with the aetiology of retrobulbar neuritis disseminated sclerosis receives no mention, and Leber's disease is omitted from the causes of optic atrophy.

Some ophthalmic surgeons would not agree with the statement that in the treatment of syphilitic lesions of the optic nerve antiluetic measures should be vigorously administered. The description of glioma gives the reader the impression that glioma occurs only as a single nodule and that this is a point of differential diagnosis from miliary tubercles which are multiple, no mention being made that multiple nodules of glioma are not infrequent. The pathology of this neoplasm is inaccurately set out and the coloured illustration of it could by no means be recognized as a typical example.

The coloured plates of angeoid streaks, retinitis juxta-papillaris and coloboma of the optic nerve in the reviewer's opinion do not afford the reader typical pictures of these diseases.

The book is well produced, the print being large and easily readable and the illustrations clear.

\title{
CORRESPONDENCE
}

\section{BROADCASTS ON OPHTHALMOLOGICAL SUBJECTS}

To the Editors of THE BRITISH JOURNAL OF OPHTHALMOLOGY.

DEAR SIRS, - A broadcast talk was given anonymously on February 27 (National and London Regional) on "The Squinting Child." It was one of a series of medical talks entitled "Take it in Time." I should be grateful for information about the response to this as regards patients attending hospital, or privately, as the result of "What the doctor said on the wireless?" Medical talks in 
general are undoubtedly popular with many people, but the B.B.C. are interested in any evidence showing that such talks have a good effect.

Yours faithfully,

THEODORE H. WhitTINGTON,

146, Harley Street, W.1

May 27, 1937.

\section{OBITUARY}

\section{N. C. RIDLEY}

Ophthalmology in the Midlands and more especially some of his nearest and dearest friends in that profession have suffered a great and irretrievable loss in the passing of Mr. N. C. Ridley of Leicester. For over forty years he had conducted one of the largest practices in the Midlands with great honour and distinction to himself and has given of his best to many thousands of patients, to whom his name was a household word and who will never cease to remember the benefits they received from his exceptional skill and long experience. His invariable and infectious cheerfulness during a long life of bodily affliction was an example to us all, and those who knew him intimately were astonished at his pluck in face of all his disabilities. He was perhaps best known to the members of the Oxford Ophthalmological Congress where his genial presence will be very much missed.

He was a founder and an original member of the Council of the Congress, and he never, by any chance, missed the Annual Meeting. He was also a founder and Past President (1915-1917) of the Midland Ophthalmological Society and the members of that Society have reason to be grateful to him for providing many excellent meetings at Leicester.

Nicholas Charles Ridley was born April 6, 1863, the eldest son of the Rev. Charles George Ridley, Vicar of Bratoft, Lincolnshire. He was educated at Boston and proceeded to St. Mary's Hospital, where he qualified and then acted as House Surgeon to the late Mr. Edmund Owen. He entered the Navy as Surgeon, being second out of 40 examined, but unfortunately after a few years' service was invalided out, on account of ankylosis of a knee due to pyogenic infection following fever.

$\mathrm{He}$ then specialized in ophthalmology and became Clinical Assistant to Mr. Silcock at Moorfields, afterwards becoming temporary Curator for five months in the absence of $\mathrm{Mr}$. Treacher 